\title{
The Impacts of Transportation Sustainability on Higher Education in China
}

\author{
Daqing $\mathrm{Zu}{ }^{1}$, Kang Cao ${ }^{2}$ and Jian $\mathrm{Xu}^{1, *}$ \\ 1 School of Foreign Studies, China University of Mining and Technology (Xuzhou), Xuzhou 221116, China; \\ dqzu@cumt.edu.cn \\ 2 Department of Regional and Urban Planning, Zhejiang University, Hangzhou 310058, China; k_cao@126.com \\ * Correspondence: jansenxu@hotmail.com
}

check for updates

Citation: Zu, D.; Cao, K.; Xu, J. The Impacts of Transportation

Sustainability on Higher Education in China. Sustainability 2021, 13, 12579.

https://doi.org/10.3390/su132212579

Academic Editors: Mengqiu Cao,

Elżbieta Macioszek, Claire Papaix, Tianren Yang and Benjamin Büttner

Received: 15 September 2021

Accepted: 12 November 2021

Published: 15 November 2021

Publisher's Note: MDPI stays neutral with regard to jurisdictional claims in published maps and institutional affiliations.

Copyright: (C) 2021 by the authors. Licensee MDPI, Basel, Switzerland. This article is an open access article distributed under the terms and conditions of the Creative Commons Attribution (CC BY) license (https:/ / creativecommons.org/licenses/by/ $4.0 /)$.
Abstract: Improving transportation sustainability serves as a means of reducing the perceived and real distance, thereby contributing to the city and higher education development. In this paper, the complexity of transport sustainability is measured via four different dimensions: economy, society, environment and politics. The variables are designed by the four dimensions. The higher education development is measured via the ratio of higher education degree holders, reflecting the skilled work mobility. Over the last 30 years, university students moving to cities for study and work purposes have become an important part of rural-urban transition mobility. However, few studies have explored the impacts of transportation sustainability on higher education development in China. The economic, environmental, social and political dimensions in transportation sustainability can boost China's higher education attainment in different ways. Against this background, this study, drawing on the panel data and employing the spatial multilevel model, investigated the impacts of transportation sustainability on higher education in China, adding new empirical evidence for China's higher education development. A panel analysis revealed that the increase in transportation sustainability induces the growth of higher education. Moreover, higher education attainment showed significant spatial dependence at the county level and had significant spatial clustering of county-level higher education attainment across provinces. Furthermore, modeled test results showed that the spatial multilevel model was more suitable for our study than traditional regression models. By identifying transport sustainability variables that have an effect on higher education, this study is the first to uncover the complexity of transportation sustainability and contributes to the latest policy implications for promoting higher education attainment through sustainable transportation.

Keywords: transportation sustainability; higher education; university students; skilled work; spatial multilevel analysis

\section{Introduction}

Modern transportation mode choices such as air transportation and high-speed railways have connected distant regions, thereby contributing to accessibility through boosting opportunities for individuals to study, work, and even migrate to distant areas [1]. Although there is emerging research that focuses on the positive role of transport in an area's development [2-6], it has not yet been addressed that transportation sustainability affects interregional long-distance mobility, migration of high-end, and high-skilled human capital [6,7]. Therefore, this study contributes to understanding the associations between sustainable transportation and higher education development through choosing key variables that reflect the effects of transportation sustainability on higher education attainment and then providing empirical evidence and implications for the growth dynamics and competitiveness of regions.

Growing transportation demand has led to a series of problems such as traffic congestion and pollution, consequently creating barriers to regional development. Under this circumstance, sustainability is introduced to transportation studies, encompassing a holistic consideration 
of environmental, social, and economic progress [8]. In this study, we follow the definition of transportation sustainability provided by the Centre for Sustainable Transportation (CST). The CST built on the debates proposed by the Organization for Economic Co-operation and Development (OECD) and then established the definition of sustainable transportation: "it ensures the basic needs of individuals and societies to be met safely and in a manner consistent with human and ecosystem health, with equity both within and between generations; It is affordable, operates efficiently, offers choice of transport mode, and supports a vibrant economy; and it limits emissions and waste to those within the planet's ability to absorb them, minimizes consumption of nonrenewable resources, limits consumption of renewable resources to the sustainable yield level, reuses and recycles components, and minimizes the use of land and the production of noise". In order to achieve transportation sustainability, policymakers need to monitor and evaluate the sustainability of transportation systems [9]. Thus, in the evaluation process, transportation sustainability is evaluated using a series of indicators and criteria [8]. Mahdinia et al. [10] studied 89 sustainable transportation indicators and used them to develop a measuring framework algorithm that considers the variables' inter-correlations and ensures that several numbers of indicators are proposed. In the study by Mahdinia et al. [10], three dimensions (environmental, social, and economical) were identified and divided and then included in the algorithm, and their subcategories were also defined. In the present study, we also followed the existing research and evaluated transportation sustainability from economic, social, and environmental dimensions.

There is emerging research examining the impacts of transport development on work [11], but minimal studies have investigated the impacts on higher education development. We measured higher education development according to the share of adults with at least a bachelor's degree to the working population since it can reflect the impacts of skilled workers on the population and growth within a region [12]. It is expected that the elasticity of transportation sustainability on higher education attainment would be larger compared to previous studies, due to the imbalanced transportation development and distorted labour markets in China. Considering the achievement of sustainable and balanced development, higher education resources should be better allocated between developed and less-developed regions.

Across the background in which China visualizes innovation and sustainability as important tasks [13], this study focuses on the unbalanced development of transportation and higher education attainment in China. Additionally, because China is facing significant inequality in higher education development and transportation sustainability, it is necessary to explore the impacts of transportation sustainability on higher education in the Chinese context. In order to investigate the development of the skilled work, economic upgrade, and higher education [14], drawing on data from the official provincial statistical yearbooks and China City Statistical Yearbooks from 2010-2020, this study answers the following research question: What are the associations between transportation sustainability and China's higher education based on the measure of sustainable transport development? With the help of a spatial multilevel analysis, we provide an empirical analysis for understanding the various dimensions of transportation sustainability and its impacts on higher education. Through answering the above research question, this study contributes to the extant body of literature by focusing on the case of China's sub-national policies and provides policy implications for transportation and higher education development planning.

\section{Literature Review}

Emerging research is developing reliable and meaningful indicators of transportation sustainability. The OECD defines sustainable transportation indicators as statistical measures that provide an indication of social, environmental, and economical sustainability [15]. Mahdinia et al. [10] measured transportation sustainability based on an indicator-based algorithm, with a focus on U.S. states, encompassing environmental, social, and economical dimensions, helping to build and analyze a comprehensive indicator system consisting 
of 89 sustainable transportation indicators. It is worth noting that different indicators could be adopted based on data availability [10]. Existing studies provide rich systems of indicators in terms of transportation studies, allowing the recognition of the indicator selection. The process of indicator selection should be driven by research questions and practical needs [16,17]. In line with recognizing specific questions, indicators should be designed as understandable, reasonable, measurable, quantifiable, accessible, and changeable $[16,18]$. Due to the growing research interests in indicator design (the selection of particular indicators within a study) for sustainable transportation, there are a large number of systematic literature reviews providing a comprehensive overview of sustainable transportation indicators $[19,20]$. Through these systematic reviews, this complexity-in an integrated and holistic manner of sustainable transportation-can be understood and addressed. Building on a systematic review of Lopez-Arboleda, Sarmiento, and Cardenas [19], it was found that many existing studies investigate transportation sustainability from the economic and environmental dimensions. However, scarce research has focused on social development. The holistic and systematic integration of the social dimension could provide a better understanding of the transportation sectors [19]. These systematic reviews offer a bigger picture for the study and selection of sustainable transportation indicators.

A small body of research has directly investigated the effects of transportation sustainability on higher education attainment or skilled work/migration [21,22]. The current literature is focused mainly on the impacts of transportation development on various types of human resources in the job market. Most studies have found that advanced transportation can significantly improve employment rates $[23,24]$. In addition, political recognition of transportation or the improvement of the government's transportation management ability is considerably important for work mobility and employment [25,26]. However, the relationship between transportation sustainability and work attraction or higher education attainment is unclear. On one hand, regions with better transportation development have higher rates of employment or higher education [21]. In contrast, only minor research shows that regions with advanced transportation development have good sustainability, let alone the relationship between this sustainability and higher education or the job market.

In addition, some previous studies underline the importance of transportation flexibility to the extent of job-education mismatch $[27,28]$. The extent of higher education attainment may be a reflection of transportation-constrained job hunting, which in turn relies on the spatial distribution of job markets and the individual's spatial flexibility [29]. For example, in Germany, public transportation availability is significantly related to a lower probability of education, while the results are different from an increase in travel time to the nearest agglomeration [29]. Moreover, advanced public transportation can decrease the effects of higher commuting distance on a lower probability of over-education [30]. Thus, advanced public transportation development can reduce the risk of job-higher education mismatch. Based on the mobility distance between higher education cities and working cities, Hensen et al. [31] concluded that graduates who enjoy better public transportation have reasonably higher education levels. However, talents experiencing long-distance mobility may have a lower possibility of reasonably higher education attainment [32]. On the other hand, transportation sustainability - shown by the regional quality of road infrastructures - is negative to higher education and the job market [33]. To conclude, transportation development is associated with the match quality between occupation and higher education [34,35].

Moreover, the relationships between public transportation development or policies and higher education are indicated by the inequalities in education and transport infrastructure. Transportation distance to education is important for promoting a more equitable supply of jobs to diverse groups [36]. Thus, job market accessibility, based on particular transport modes, has received increased attention in previous studies [37], and these studies based on education accessibility have considered the socioeconomic indicators as well as school outcomes [38,39]. In addition, as a dynamic and highly political production, public 
transportation is significant for explaining the associations between transportation progress and education inequalities and the extent to which they are mutually strengthened [36].

Specifically, Harland and Stillwell [40] studied transport for school planning by exploring the movement between schools and residences. In order to establish a sound model, variables including school rolls, commuting distances, pupil mobility, residential migration, pupil gender, and ethnicity were selected. The established model provided analytical results showing the key effects of transportation on school planning. Contrasting from the study by Harland and Stillwell, Wang et al. [41] investigated freight from the perspective of China's national economic development. Their analytical results revealed that freight transport plays an important role in economic growth. In detail, the contribution of high freight-demand sectors to economic development has decreased, indicating China's economic transition [41], thus resulting in different industrial structures and geographical characteristics of each region in China. Consequently, talent mobility also indicates diversity. Although scarce research has explored the relationship between freight and education, some studies have recognized the effects of freight on talent mobility and schooling.

Considering the fact that the higher education population has a higher demand for obtaining driver's licenses and accessing different transportation modes, transportation sustainability may be of importance to the improvement or growth of regional higher education [42]. Due to high housing prices in the urban center, new urban migrants tend to live in the suburbs or far away from the city center [42]. Meanwhile, the expansion of the spatial distance of the labour force entering the job market also promotes the continuous improvement of transportation technology resulting in sustainability [43]. Therefore, the sustainability of transportation is of great significance to the healthy development of cities and the improvement of the quality of life of higher education workers.

\section{Methods}

\subsection{Data and Variables}

We obtained data from second-hand sources and also from China's Statistical Yearbooks of Provinces, China's Statistical Yearbooks of Transportation, China Industrial Statistics Yearbooks, China City Statistical Yearbooks, and China Social and Economic Statistical Yearbook in counties/county-level cities, and Statistics of China's Ministry of Education. The range of the data was from 2015-2019.

The complex and dynamic process of transportation sustainability involves the interaction between economic, social, environmental, and political factors. Thus, in order to explore the reason for transportation sustainability affecting higher education, the study examines the potential determinants from four aspects of the economy, society, environment, and politics (Table 1). A large number of existing studies have examined the influence of transport development on work [11,44]; however, scant literature has directly focused on transportation sustainability and higher education or skilled work. Moreover, the study focuses on the different levels, and thus, we expect that the determinants might produce different impacts due to spatial disparities.

The indicator choice in the economic aspect mainly considers transportation investment, transportation employment, and transportation freight. Therefore, the study selects transportation expenditures in infrastructures per GDP per capita (EI) to test the economic effects of transportation infrastructures. Existing studies have indicated the spatial inequalities in transportation infrastructures and strong relations between transportation infrastructures and economic activities $[45,46]$. Due to different spatial levels, the economic role of transportation infrastructures depends on the different economic development levels and governmental supports. In order to clarify the expenditure benefit of transportation systems users, this study uses public transportation expenditures per capita (PE). By choosing this indicator, we expect to improve the higher education level by increasing the benefit and decreasing the expenditure of transportation systems users [10]. In terms of transportation employment, the number of public transportation employment per capita (NE) is selected to reflect the expenditure and revenue of transportation systems 
operators. Existing studies have also suggested that high transportation employments can attract greater migration due to the propensity to earn higher wages and coordinated employment transportation plans $[47,48]$. We selected freight shipment by rail per capita (FR) to show transportation benefits. Based on the existing research, freight has effects on school planning and work/talent mobility $[40,41]$, so in this study, we also considered relevant variables including freight shipment by rail per capita. Previous studies also show that sustainable transportation development can benefit transportation revenue however, the results rely on local tax policies [49].

Table 1. Variables to measure transportation sustainability.

\begin{tabular}{|c|c|c|}
\hline \multicolumn{2}{|c|}{ Variables } & Definition \\
\hline \multirow{4}{*}{ Economy } & EI & Transportation expenditures in infrastructures per GDP per capita \\
\hline & $\mathrm{PE}$ & Public transportation expenditures per capita \\
\hline & NE & Number of public transportation employments per capita \\
\hline & FR & Freight shipment by rail per capita \\
\hline \multirow{5}{*}{ Society } & TA & Transportation accidents per capita \\
\hline & TD & Transportation accident deaths per capita \\
\hline & NV & Total number of vehicles per capita \\
\hline & VR & Total length of motor vehicle routes per capita \\
\hline & $\mathrm{TM}$ & Number of available transportation modes \\
\hline \multirow{4}{*}{ Environment } & GE & Greenhouse gas emissions by transportation per capita \\
\hline & $\mathrm{TN}$ & Transport noise per capita \\
\hline & RE & $\begin{array}{c}\text { Renewable energy consumption per total transportation energy } \\
\text { consumption }\end{array}$ \\
\hline & RL & Total urban roads length per capita \\
\hline \multirow[t]{2}{*}{ Politics } & PT & $\begin{array}{l}\text { Proportion of the number of public policies in transportation to the } \\
\text { total number of public policies }\end{array}$ \\
\hline & $\mathrm{TL}$ & Closure rate of transportation law cases \\
\hline
\end{tabular}

Regarding the social dimension, this study focuses on the perspectives of safety, accessibility, and transportation diversity. For the safe aspect, we select two indicators: transportation accidents per capita (TA) and transportation accident deaths per capita (TD). Transportation safety is viewed as a strong predictor for traffic crashes and social welfare in the existing literature, and it is suggested that transportation safety can provide a powerful policy incentive for social and economic growth [50,51]. In order to test the sustainability in accessibility, the total number of vehicles per capita (NV) and total length of motor vehicle routes per area (VR) are selected. Using these two indicators, the study sets out to enhance the accessibility of transportation systems, so as to promote regional higher education attainment. In the literature, accessibility to transportation infrastructure could attract more skilled workers by promoting industrial clusters [52]. Moreover, improved transportation accessibility can help bring job opportunities closer to workforces [53]. In addition, within the social dimension, we hope to improve transportation sustainability by increasing the diversity of transportation modes. Thus, the study selects a number of available transportation modes (TM). Due to rapid urban development, the number of transportation modes is constantly increasing. Therefore, we examine whether the increase in transportation diversity can help attract more skilled workers with higher education.

In terms of the environmental dimension, the study begins from the perspectives of pollutant emissions, energy utilization, and land efficiency of transportation. Previous studies have shown that the two most important aspects of traffic pollution are greenhouse gas emissions and noise pollution $[53,54]$. Consequently, greenhouse gases emissions by 
transportation per capita (GE) and transport noise per capita (TN) are selected. Existing studies have indicated that traffic pollution emissions have led to increasing gaps both within and between cities [55]. These gaps impact the urban attraction to skilled workers with higher education, which further exacerbates regional and urban inequalities. In order to arrive at sustainable transportation, the aim of energy utilization is to reduce petroleum dependence and use renewable energy [10]; thus, renewable energy consumption per total transportation energy consumption (RE) is chosen to test the effects. The positive role of renewable energy in regional and urban growth and work has been clarified in the literature [56,57]; in particular, renewable electricity support policies can raise the equilibrium unemployment rate by $0.1-0.3 \%$ [58]. Thus, high renewable energy consumption in a region can bring more workers with higher education. In terms of land efficiency of transportation, this study uses total urban roads length per capita (RL) because the improvement in interregional transportation could benefit land-use efficiency and work mobility [59].

Although some studies have indicated the relationships between governance and public factors and transportation or higher education [60,61], little effort has been made to clarify the effects of political factors in transportation sustainability on higher education. In the field of transportation sustainability, the politics dimension is used to capture the transportation governance theme. Connecting to our case, we select a proportion of transportation public policies to the total number of public policies (PT), and the closure rate of transportation law cases (TL). The existing literature argues that politics can help to decrease inequalities by transportation development, and the improvement of institutional quality - led by transportation development-can promote the mobility of skilled workers [62-64]. Thus, the study argues that high institutional quality in transportation is a reflection of sustainability and can increase higher education attainment. The data in the study are from province statistical yearbooks and China City Statistical Yearbooks from 2010-2020. The indicators on policies are from pkulaw.com. In addition, this study also includes some control variables-socio-demographic index (SDI). The SDI was constructed by Kassebaum et al. and measures, by income per capita, the average years of schooling and total fertility rate [63]. Urbanization and GDP are chosen to measure county-level socioeconomic development. Urbanization is measured by the ratio of the urban population [62,65]. In our study, we followed the existing research, measuring urbanization by the ratio of the urban population. Based on the human development index (HDI) method [66], the SDI values are from 0 to 1, and the Jenks method is employed to generate five classes of SDIs-SDI 1 indicates the lowest level and SDI 5 indicates the highest.

\subsection{Method}

This study employs a spatial multilevel analysis to explore the effects of transportation sustainability on higher education attainment. Due to the significantly high spatial auto-correlation coefficients and significant differences across different regions in China, we decided to use spatial multilevel analysis. Compared with traditional multilevel analysis, a spatial multilevel analysis adds spatial auto-correlated residuals to a standard multilevel model with random intercept [67]. We first calculate Moran's index and Local Moran's index to show spatial autocorrelation. The Moran index refers to a kind of spatial autocorrelation coefficient, which is used to judge whether there is autocorrelation in space [67]. Local Moran's index examines the individual locations, ensuing hotspots to be identified, building on a comparison with the neighboring samples [67]. Weights in this study are produced by rook contiguity relations between pairwise units. Then, the variance components model is used to test the significance of provincial heterogeneity in county-level higher education attainment. The function of this model follows:

$$
H E A_{i j}=\beta_{0}+\varepsilon_{i j}+\mu_{j}\left[\mu_{j} \sim N\left(0, \sigma_{\mu}^{2}\right) ; \varepsilon_{i j} \sim\left(0, \sigma_{\varepsilon}^{2}\right)\right]
$$


where $H E A_{i j}$ is the higher education attainment for $i$ county in $j$ province. $\beta_{0}$ is the overall mean of HEA across all groups. $\varepsilon_{i j}$ indicates the residuals at the county level, and $\mu_{j}$ shows the residuals at the provincial level. $\varepsilon_{i j}$ and $\mu_{j}$ follow a normal distribution. If the residual is normally distributed, we take it as random. If it is random, it fits better to the random error.

In order to avoid the biased estimation in standard errors resulting from a standard regression model [68], the study employs spatial multilevel models with spatial errors. This model allows us to add spatial autocorrelation residuals to standard multilevel models with random intercepts. Thus, the specification of the spatial multilevel analysis in the study is:

$$
\begin{gathered}
H E A_{i j}=\beta_{0}+\sum_{n=1}^{m} \beta_{n} T S_{n i j}+\sum_{t=1}^{r} \beta_{t} T S_{t j}+\varepsilon_{i j}+\mu_{j} \\
\varepsilon_{i j}=\lambda \sum_{j=1}^{k} w_{i j} \varepsilon_{i j}+\zeta_{i j} \\
\mu_{j} \sim N\left(0, \sigma_{\mu}^{2}\right) ; \zeta_{j} \sim N\left(0, \sigma_{\zeta}^{2}\right)
\end{gathered}
$$

where $\beta_{n}$ and $\beta_{t}$ (in Equation (2)) are the coefficients at county and provincial levels, respectively; $m$ and $r$ are the number of variables at county and provincial levels, respectively; $\lambda$ indicates the degree of spatial dependence; $\mathrm{k}$ shows the number of neighbors in $\varepsilon_{i j} ; w_{i j}$ is the spatial contiguity weight matrix, and $w_{i j} \varepsilon_{i j}$ presents the spatial errors; $\zeta_{i j}$ is random error, and together with $\mu_{j}$, they both follow a normal distribution.

Our study highlights the importance of contextual effects and spatial dependence, the associations between transportation sustainability and higher education attainment, and the intersections of transportation sustainability and economic growth impacting higher education attainment. Referencing the study of $\mathrm{Gu}$ et al. [67], our study implements 18 sub-models. The aim of Model 1 is to examine the significance of group effects (higher education attainment at the provincial level) in comparison to a one-level model. Model 1 belongs to the variance components model, which contains only one constant. In order to explore the determinants and to compare their importance, the spatial errors of higher education attainment, economy, society, environment, and politics are added from Models 2-6, respectively. Model 7 examines the joint effects of spatial error and transportation sustainability. Based on Model 7, Model 8 adds socioeconomic indicators at the country level. Model 9 includes all the variables. Models 10-18 test the interactions between transportation sustainability and the urban socio-demographic index, which helps to further understand the potentially different influences of transportation sustainability on higher education attainment under different contextual backgrounds. In the study, the socio-demographic index includes a common logarithmic transformation of the gross domestic product (GDP) and the proportion of the population living in the urban district.

In order to avoid the multicollinearity between independent variables, the study conducts the Pearson correlation coefficients test between pairwise variables. In addition, we use the Akaike Information Criterion (AIC) to indicate the fitness of models since it combines fit goodness with variables' complexity [69]. Moreover, the robustness associations between transportation sustainability and higher education attainment are examined through exploring the potentially lagged effects of previous transportation sustainability.

\section{Results and Analysis}

The potential roles of China's transportation sustainability on higher education attainment at the county level have not been given much attention previously. Our study explores the associations between transportation sustainability, including economy, society, environment and politics, and higher education attainment. We consider the spatial autocorrelation of higher education attainment across the country and the potential spatial clustering of higher education attainment across provinces. Table 2 depicts the results of the Pearson correlation analysis. According to Table 2, except for TM, other determinants are positively related to HEA. In these variables, TA, VR, PT, and log(GDP) have higher 
coefficients. In addition, NE, TM, and RE are statistically insignificant. Moreover, the results of the Pearson correlation coefficients also indicate that collinearity does not significantly influence the analysis. Collinearity is always an issue in statistical analysis, in which its existence must be acknowledged and dealt with accordingly. However, after the models were tested by Pearson correlation, it was confirmed that the existence of collinearity did not significantly affect the models' results.

Table 3 shows the results of transportation sustainability affecting higher education attainment within the framework of spatial multilevel models. Determinants with significant coefficients in Models 2-6 are presented. The changes in AIC values indicate that the spatial dependence (6352.4) of higher education attainment contributes most in understanding the variation in higher education attainment, followed by the politics factor (PT) (6428.3). In comparison, determinants at the provincial level have the least exploratory power. According to Models 7 and 8, after incorporating county-level socioeconomic indicators, the variables PE, TM, and RL are no longer significant. For most of China's counties, public transportation is unsound, and people prefer private vehicles (i.e., private electric bicycles), therefore, PE is statistically insignificant. The limited transportation choice across counties means that the variables PE, TM, and RL have different results among Models 7 and 8 . After considering the provincial-level SDIs, Model 9 suggests that when we control other factors, the higher education attainment in less-developed provinces (SDI 1) is generally lower than those in medium-level development (SDI 3). Meanwhile, the smaller AIC values also indicate that the predictors at the country level have better explanatory powers than those at the provincial level.

Regional effects and spatial autocorrelation should be explored to consider the associations between transportation sustainability and higher education attainment at different spatial scales. Spatial multilevel models have better suitability than regular regression models in examining the association between transportation sustainability and higher education attainment. This can be supported by the significant effects at the province level on county-level higher education attainment and the spatial autocorrelation of county-level higher education attainment and residuals. Meanwhile, in order to avoid the estimation bias of standard errors resulting from spatial homogeneity or spatial heterogeneity, we further emphasize the importance of considering both spatial homogeneity and spatial heterogeneity in studying transportation and education data with spatial structure [70]. The results of spatial multilevel models suggest that transportation sustainability plays a significant role in higher education attainment. In particular, PT consistently maintained a significant and strong impact in Models 2-9. This result shows that the sustainability of transportation is not only reflected in the traditional three dimensions: politics, economy, and society. The political dimension is an important institutional guarantee for the in-depth development of traffic sustainability as local political preferences are able to affect the modal, costs, ridership, and route analyses of transportation [71]. Moreover, the transportation sustainability of the political dimension can help to attract workers with higher education by the political incorporation of immigrants [72].

In addition, the $\log (\mathrm{GDP})$ coefficients also indicate that politics may be a potential mediator in the association between the socioeconomic indicator and higher education attainment. The coefficients of $\log (\mathrm{GDP})$ increase and change from insignificant to significant. China's economic growth and planning are administrative driven [73,74]. Thus, transportation planning is closely related to regional politics and economic development, and better transportation planning is accompanied by reasonable politics and growth in developed provinces $[75,76]$. Thus, although numerous mediators on socioeconomic growth indirectly affect the regional attraction on higher education immigration, the politics factor also has strong potential. Moreover, when we consider the indicator from the politics dimension in Model 8, the significant coefficients of economic, social, and environmental dimensions increase. Consequently, politics quality is a potential confounder in the association between transportation sustainability and higher education attainment. This finding shows that the institutional environment has an extremely significant impact on higher education attainment. 
Table 2. Pearson correlation coefficients between variables (two-tailed test).

\begin{tabular}{|c|c|c|c|c|c|c|c|c|c|c|c|c|c|c|c|c|c|}
\hline Variables & HEA & EI & PE & NE & FR & TA & TD & NV & VR & TM & GE & TN & RE & RL & PT & TL & $\log ($ GDP $)$ \\
\hline EI & $0.21^{* *}$ & & & & & & & & & & & & & & & & \\
\hline PE & $0.32 *$ & $0.16^{*}$ & & & & & & & & & & & & & & & \\
\hline $\mathrm{NE}$ & 0.14 & $0.15 *$ & $0.29 *$ & & & & & & & & & & & & & & \\
\hline $\mathrm{TA}$ & 0.97 * & $0.17^{* *}$ & $0.88^{*}$ & 0.13 * & 0.41 * & & & & & & & & & & & & \\
\hline TD & 0.23 ** & -0.05 & 0.11 * & 0.48 * & 0.29 * & 0.28 * & & & & & & & & & & & \\
\hline NV & 0.55 * & 0.40 * & $0.78 *$ & 0.15 * & 0.23 * & 0.31 * & 0.15 & & & & & & & & & & \\
\hline VR & $0.85^{* *}$ & $0.18^{*}$ & 0.05 & 0.12 & 0.72 * & 0.13 & 0.06 * & $0.06^{*}$ & & & & & & & & & \\
\hline GE & 0.22 ** & 0.07 & 0.28 * & $0.49 *$ & 0.25 * & $0.36^{*}$ & 0.73 * & 0.27 * & -0.1 & 0.14 * & & & & & & & \\
\hline $\mathrm{TN}$ & 0.64 * & 0.22 * & 0.70 * & 0.09 & 0.40 * & 0.55 * & 0.14 * & 0.32 * & 0.13 * & 0.09 * & $0.16^{*}$ & & & & & & \\
\hline $\mathrm{RE}$ & 0.07 & 0.64 * & $0.66^{*}$ & $0.27 *$ & 0.33 & 0.1 & 0.22 * & 0.13 * & 0.73 & 0.28 ** & 0.24 * & 0.26 * & & & & & \\
\hline RL & 0.11 * & 0.21 * & $0.15^{* *}$ & 0.40 * & $0.46^{*}$ & 0.12 & 0.09 & 0.21 * & 0.28 * & 0.03 & 0.1 & 0.62 * & 0 & & & & \\
\hline $\mathrm{PT}$ & $0.89 *$ & 0.15 & 0.19 * & $0.43 *$ & 0.17 * & 0.47 * & 0.33 * & 0.37 * & 0.24 * & 0.81 * & $0.17^{*}$ & $0.41 *$ & 0.24 * & $0.41 *$ & & & \\
\hline $\mathrm{TL}$ & 0.38 * & 0.13 & $0.81^{* *}$ & 0.24 * & 0.60 * & $0.20^{* *}$ & 0.15 * & $0.25^{* *}$ & 0.51 * & 0.23 * & 0.28 * & 0.64 * & 0.13 & 0.34 * & 0.42 * & & \\
\hline $\log (\mathrm{GDP})$ & 0.70 * & 0.25 * & 0.69 * & $0.27^{* *}$ & $0.25^{* *}$ & 0.23 * & 0.66 * & 0.45 * & 0.11 & 0.17 * & $0.16^{*}$ & 0.17 & 0.12 * & $0.13^{* *}$ & 0.25 * & 0.37 * & \\
\hline Urbanization & 0.36 * & 0.09 & $0.21^{* *}$ & 0.34 * & 0.27 * & 0.14 & 0.18 * & 0.12 & 0.3 & $0.49^{* *}$ & $0.04^{* *}$ & $0.19 * *$ & 0.02 & $0.17^{*}$ & 0.31 * & 0.31 * & $0.54^{* *}$ \\
\hline
\end{tabular}
Note: ${ }^{* *} p<0.01 ;{ }^{*} p<0.05$ 
Table 3. Results from spatial multilevel models.

\begin{tabular}{|c|c|c|c|c|}
\hline Variables & Models 2-6 & Model 7 & Model 8 & Model 9 \\
\hline \multicolumn{5}{|c|}{ Spatial error $(\mathrm{AIC}=6352.4)$} \\
\hline$\lambda$ & $0.512 * *$ & $0.194^{* *}$ & $1.323^{* *}$ & $0.648^{*}$ \\
\hline \multicolumn{5}{|c|}{ Economy $(\mathrm{AIC}=6517.3)$} \\
\hline PE & $0.225 * *$ & $0.151^{* *}$ & 0.031 & 0.181 * \\
\hline FR & -0.104 & $0.332^{* *}$ & $0.511 *$ & $0.657^{* *}$ \\
\hline \multicolumn{5}{|c|}{ Society $(\mathrm{AIC}=6652.1)$} \\
\hline TA & $-0.166^{*}$ & $-0.743 *$ & $-0.227 *$ & $-0.513^{* *}$ \\
\hline NV & $0.087^{* *}$ & $0.124^{* *}$ & $0.131 * *$ & $0.073^{* *}$ \\
\hline $\mathrm{TM}$ & $0.748^{* *}$ & $0.076^{*}$ & 0.095 & $0.161 *$ \\
\hline \multicolumn{5}{|c|}{ Environment (AIC = 6719.9) } \\
\hline GE & $-0.115^{*}$ & $-0.227^{* *}$ & $-0.345^{* *}$ & $-0.357^{* *}$ \\
\hline RE & $0.113 *$ & $0.156^{* *}$ & $0.654^{* *}$ & $0.247^{* *}$ \\
\hline RL & $0.436^{* *}$ & $0.162 *$ & 0.265 & $0.208^{* *}$ \\
\hline \multicolumn{5}{|c|}{ Politics (AIC = 6428.3) } \\
\hline $\mathrm{PT}$ & $0.315^{* *}$ & & $0.393 * *$ & $0.327^{* *}$ \\
\hline \multicolumn{5}{|c|}{ Socioeconomic indicators $(\mathrm{AIC}=6557.6)$} \\
\hline $\log (\mathrm{GDP})$ & 0.283 & & $0.145^{* *}$ & $0.362 * *$ \\
\hline \multicolumn{5}{|c|}{ Provincial level $(\mathrm{AIC}=6798.8)$} \\
\hline SDI 1 & $-0.804^{* *}$ & & & $-0.568 * *$ \\
\hline SDI 2 & $-1.001^{* *}$ & & & -0.174 \\
\hline SDI 4 & 0.191 & & & $0.146^{* *}$ \\
\hline SDI 5 & $0.804^{* *}$ & & & $0.173 *$ \\
\hline AIC & & 5231.4 & 5587.1 & 5726.3 \\
\hline
\end{tabular}

Note: ${ }^{* *} p<0.01 ;{ }^{*} p<0.05$. Variables that were insignificant in the models were excluded.

Table 4 shows the results from the spatial multilevel analyses of higher education attainment on interactions of transportation sustainability and SDIs. In Model 10, the association between PE and higher education attainment at the county level is significant, and the interaction of PE and SDI 1 is significantly higher than that of PE and SDI 3. The FR holds similar results to PE. Moreover, in Model 11, both the interactions of FR and SDI 1 and SDI 2 are significantly higher than that of PE and SDI 3. In Model 12, although the coefficient of TA is insignificant in the main part, a higher number of transportation accidents can significantly reduce the higher education attainment in SDI 1. Model 13 shows that the increasing number of vehicles (NV) per capita is significantly linked to higher education attainment. Moreover, the interactions between NV and SDI 1 and SDI 4 are significantly positive, meaning that NV can help less-developed and developed provinces attract more skilled workers. On the contrary, Model 14 shows that a higher number of available transportation modes (TMs) can promote the attraction of higher education in less-developed provinces, whereas the interaction of TM and developed provinces is not significant. The greenhouse gas emissions indicator, by transportation per capita (GE), is significantly negative to higher education attainment in the main part of model. However, the interactions of GE and SDIs indicate that the negative effects are significant in less-developed provinces; however, developed provinces retain their attraction to talent due to the increase in greenhouse gas emissions. Model 16 gives us the results of renewable energy consumption (RE). Overall, RE is significantly positive to higher education attainment. In particular, according to the interaction of RE and SDI 4 and SDI 5 , the increased consumption of renewable energy can help developed provinces 
obtain higher education attainment. Regarding the result of total urban roads length per capita (RL), it has, overall, significant positive impacts on higher education attainment. However, when we observe the interactions, increasing urban roads length per capita could decrease the higher education attainment in less-developed provinces $(-0.121)$, whereas it has strong positive effects in developed provinces (1.304). In Model 18, the result of the politics dimension (PT) suggests that the policy bias in the field of transportation is significantly linked to higher education attainment in the main part (0.166). Moreover, after the interaction items are included, the transportation political preference in less-developed provinces has great attraction for higher education talents.

Table 4 indicates that the intensity of potential influences of transportation sustainability on higher education attainment varies within the different levels of contextual backgrounds. Overall, less-developed provinces are affected more significantly, while developed provinces still maintain a strong attraction. Especially, regarding the interaction with less-developed provinces (SDI 1 and SDI 2), PE, FR, NV, TM, and PT have significant and positive effects. Increasing public transportation expenditures can promote more work with higher education by inducing private mobility systems to afford larger expenditures in transportation, so as to augment their relative convenience in less-developed regions [77]. Freight transport can contribute to economic growth in lower-middle-income regions because it improves the logistics efficiency of products and promotes market transactions between regions [78]. Thus, with the introduction of regional talent policy, developing freight transport is an important indicator of sustainability and can attract more talents. NV and TM are reflections of transportation accessibility. Previous studies have indicated that improved transportation accessibility has a strong positive impact on different job markets in low-wage job regions, and discussions on transportation accessibility can induce significant differences in regional equalities $[79,80]$ The positive impact of policy preferences on less-developed regions is obvious, and they are viewed as an effective tool with which to promote regional equalities. On the contrary, TA, GE, and RL are negative within the context of less-developed regions. Increasing transportation accidents not only means chaotic urban transportation planning but also reflects the lack of transportation governance. Moreover, it can also lead to low-quality citizens and stigmatize the city. Coupled with backward economic conditions, increasing transportation accidents will naturally reduce the attraction of talents in less-developed regions. As the indicators of the environmental dimension, the negative effects of GE and RL in less-developed provinces mean that health and life quality are important factors in selecting work locations [81,82].

In terms of developed provinces (SDI 4 and SDI 5), NV, RE, and RL show significant and positive interaction effects. Although some studies indicate that increasing vehicle ownership will increase energy use and $\mathrm{CO}_{2}$ emissions [83], improved social welfare and career prospects in developed regions still have a strong attraction to work with higher education [84,85]. The development of sustainable energy is mostly concentrated in technology-intensive industries. At the same time, due to rapid economic development, developed regions have a high demand for sustainable energy. Therefore, these regions require highly skilled migrants. Moreover, the development of sustainable energy technology has also greatly reduced residents' transportation and living costs in developed regions. Therefore, the interaction between the index and developed regions shows a positive effect. The increase in per capita roads in developed regions not only means reasonable transportation planning and transportation management but also indicates the further development of urbanization in a region. Moreover, the increase in roads per capita also leads to high spatial accessibility, which means that the distance from work to the market is shortened and efficiency is improved [76]. Therefore, according to the above results and analysis, Figure 1 demonstrates how transportation sustainability impacts higher education. 
Table 4. Spatial multilevel analyses of higher education attainment on interactions of transportation sustainability and SDIs.

\begin{tabular}{|c|c|c|c|c|c|c|c|c|c|}
\hline Variables & Model 10 & Model 11 & Model 12 & Model 13 & Model 14 & Model 15 & Model 16 & Model 17 & Model 18 \\
\hline$\lambda$ & $0.551^{* * *}$ & $0.361 * * *$ & $0.354^{* * *}$ & $0.565^{* * *}$ & $0.237^{*}$ & $0.451^{* * *}$ & $0.256^{* *}$ & $0.397 * * *$ & $0.429 * *$ \\
\hline PE & $0.447^{* * *}$ & $0.142 * *$ & 0.118 & 1.14 * & $0.579 * *$ & $0.495^{* *}$ & $0.616^{* * *}$ & $1.203^{* * *}$ & $0.554^{* * *}$ \\
\hline FR & 0.051 & $0.231 * * *$ & $0.501^{* * *}$ & $0.79^{* *}$ & $0.510^{* * *}$ & $0.325^{* * *}$ & $0.132 * * *$ & $0.259 * *$ & $0.451^{* * *}$ \\
\hline TA & $-0.331^{* * *}$ & 0.000 & -0.268 & $-0.721^{* *}$ & $-0.107^{* *}$ & -0.121 & -1.432 & $-0.156^{*}$ & $-0.123^{* *}$ \\
\hline $\mathrm{NV}$ & $0.159 *$ & 0.161 * & $0.419^{* *}$ & $0.461^{* *}$ & $0.151 * * *$ & $0.203^{* *}$ & $0.101^{* * *}$ & $0.045^{* *}$ & $0.074^{* *}$ \\
\hline $\mathrm{TM}$ & $0.457^{* * *}$ & $0.082 * *$ & $0.249^{* *}$ & 0.303 * & $0.021^{* * *}$ & 0.023 * & $0.091^{* *}$ & $0.019 * * *$ & $0.261^{* * *}$ \\
\hline GE & $-0.742^{* * *}$ & $-0.018 *$ & $-0.546^{*}$ & $-0.167^{* *}$ & $-0.457^{*}$ & $-0.106^{* *}$ & $-0.194 *$ & $-0.189 * *$ & -0.114 \\
\hline $\mathrm{RE}$ & $0.059 * *$ & 0.036 * & $0.319 * *$ & 0.088 & $0.108^{* * *}$ & $0.214^{* * *}$ & $0.141^{* * *}$ & $0.161^{* * *}$ & $0.451^{* *}$ \\
\hline RL & $0.092 *$ & $0.193^{* *}$ & $0.029^{* *}$ & $0.103^{* *}$ & $0.100 * *$ & $0.181^{* * *}$ & $0.061^{* * *}$ & $0.069 * * *$ & $0.079 * * *$ \\
\hline PT & $0.444^{* * *}$ & $0.499 * * *$ & $0.402 *$ & $0.563^{* *}$ & $0.293^{* * *}$ & $0.575^{* * *}$ & $0.169^{* * *}$ & $0.114^{* * *}$ & $0.166^{* *}$ \\
\hline $\log (\mathrm{GDP})$ & $0.119 *$ & $0.665^{* *}$ & $0.261^{* *}$ & $0.171^{* * *}$ & $0.081^{* * *}$ & $0.035^{* * *}$ & $0.262^{* * *}$ & $0.231^{* * *}$ & $0.203^{* * *}$ \\
\hline SDI 1 & -1.792 * & $-0.021 *$ & $-0.385^{* *}$ & -0.165 * & $-0.093^{* *}$ & -1.065 & -0.097 & $-0.284^{* *}$ & -0.140 * \\
\hline SDI 2 & $-0.011^{*}$ & $-0.222 * *$ & $-0.588^{*}$ & $-0.071^{* * *}$ & $-0.121^{* *}$ & -0.106 & $-0.072^{* * *}$ & -0.231 & $-0.144^{* *}$ \\
\hline SDI 4 & $0.001^{* * *}$ & 0.591 & 0.002 * & $0.110^{* *}$ & $0.145^{* * *}$ & $0.058^{* *}$ & $0.228^{* * *}$ & $0.170 * * *$ & $0.129^{* *}$ \\
\hline SDI 5 & $0.039^{* *}$ & 1.003 * & 0.038 & $0.022^{* *}$ & $0.043 *$ & 0.071 & $0.037^{* *}$ & $0.030^{* * *}$ & $0.084^{* * *}$ \\
\hline PE*SDI 1 & $0.149^{* *}$ & & & & & & & & \\
\hline PE*SDI 2 & 0.874 & & & & & & & & \\
\hline PE*SDI 4 & 0.361 & & & & & & & & \\
\hline PE*SDI 5 & -0.027 & & & & & & & & \\
\hline $\mathrm{FR} * \mathrm{SDI} 1$ & & $0.196^{* *}$ & & & & & & & \\
\hline FR*SDI 2 & & $0.532 *$ & & & & & & & \\
\hline FR*SDI 4 & & -1.591 & & & & & & & \\
\hline FR*SDI 5 & & 0.532 & & & & & & & \\
\hline TA*SDI 1 & & & $-0.389 * *$ & & & & & & \\
\hline TA*SDI 2 & & & -0.001 & & & & & & \\
\hline TA*SDI 4 & & & 1.902 & & & & & & \\
\hline TA*SDI 5 & & & 0.185 & & & & & & \\
\hline $\mathrm{NV}^{*}$ SDI 1 & & & & $0.104^{* * *}$ & & & & & \\
\hline $\mathrm{NV}^{*}$ SDI 2 & & & & 0.562 & & & & & \\
\hline $\mathrm{NV}^{*}$ SDI 4 & & & & $0.146^{* *}$ & & & & & \\
\hline NV*SDI 5 & & & & -0.167 & & & & & \\
\hline TM*SDI 1 & & & & & $1.008^{* * *}$ & & & & \\
\hline TM*SDI 2 & & & & & $0.081 *$ & & & & \\
\hline TM*SDI 4 & & & & & 0.537 & & & & \\
\hline TM*SDI 5 & & & & & 0.535 & & & & \\
\hline GE*SDI 1 & & & & & & $-0.305^{* * *}$ & & & \\
\hline $\mathrm{GE}^{*} \mathrm{SDI} 2$ & & & & & & 0.093 & & & \\
\hline $\mathrm{GE}^{*} \mathrm{SDI} 4$ & & & & & & 0.832 & & & \\
\hline GE*SDI 5 & & & & & & 0.344 & & & \\
\hline $\mathrm{RE}^{*} \mathrm{SDI} 1$ & & & & & & & 0.239 & & \\
\hline $\mathrm{RE}^{*} \mathrm{SDI} 2$ & & & & & & & -0.052 & & \\
\hline $\mathrm{RE}^{*} \mathrm{SDI} 4$ & & & & & & & $0.050 *$ & & \\
\hline $\mathrm{RE}^{*} \mathrm{SDI} 5$ & & & & & & & $0.021^{* * *}$ & & \\
\hline RL ${ }^{*}$ SDI 1 & & & & & & & & $-0.121 *$ & \\
\hline RL ${ }^{*}$ SDI 2 & & & & & & & & 0.146 & \\
\hline $\mathrm{RL}^{*} \mathrm{SDI} 4$ & & & & & & & & 0.082 & \\
\hline $\mathrm{RL}^{*} \mathrm{SDI} 5$ & & & & & & & & $1.304^{* *}$ & \\
\hline PT*SDI 1 & & & & & & & & & $0.254^{* * *}$ \\
\hline PT*SDI 2 & & & & & & & & & 0.182 \\
\hline PT*SDI 4 & & & & & & & & & 1.074 \\
\hline PT*SDI 5 & & & & & & & & & -0.061 \\
\hline AIC & 7423.8 & 7489.4 & 7653.2 & 7238.9 & 7781.5 & 7543.3 & 7886.4 & 7795.3 & 7854.7 \\
\hline
\end{tabular}




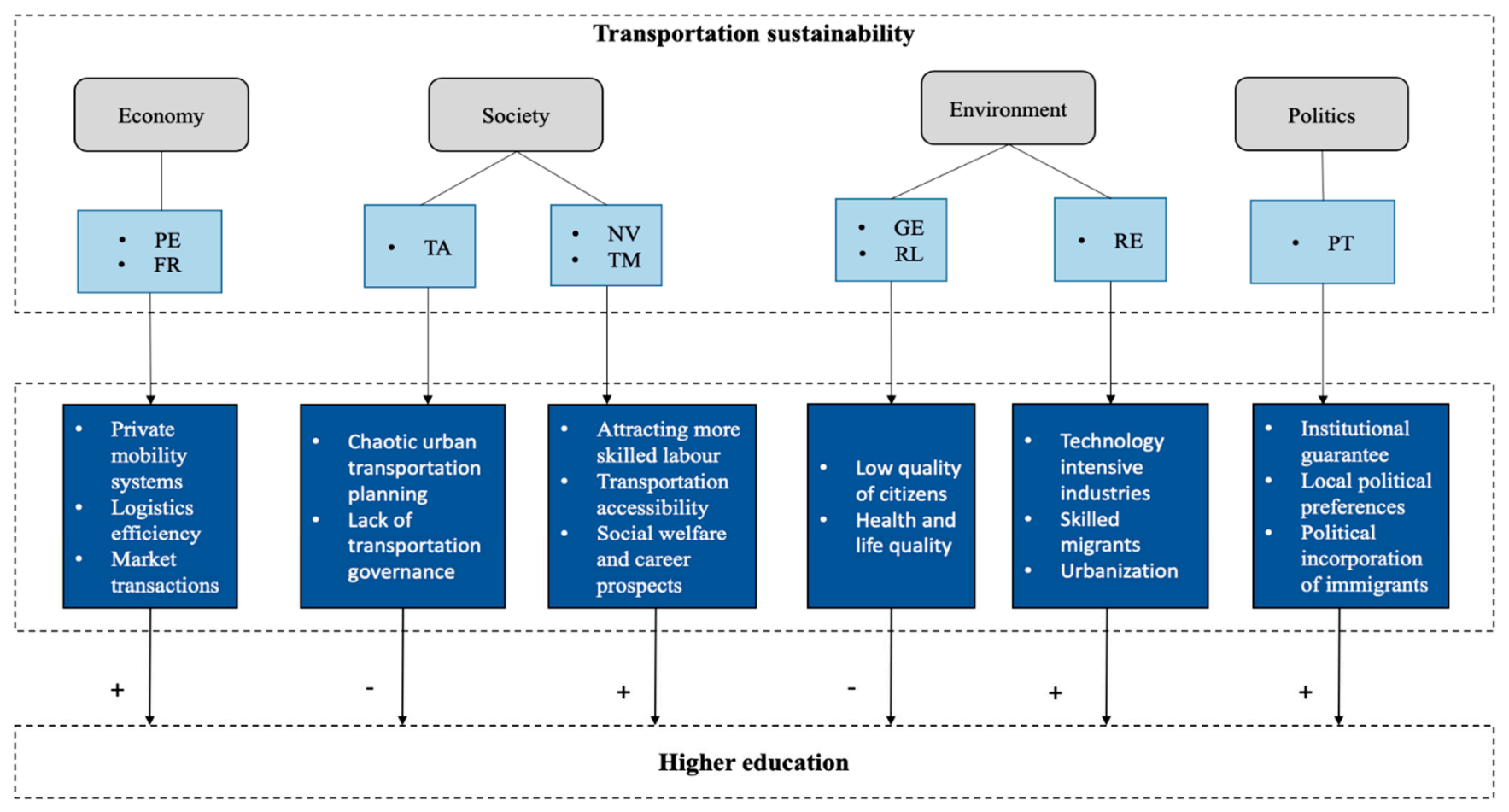

Figure 1. The mechanism of transportation sustainability affecting higher education.

\section{Conclusions}

This study examined whether the presence of transportation sustainability was currently relevant as a factor encouraging higher education attainment in China from a geographical perspective. Our empirical analysis indicates that higher education attainment had significant spatial dependence at the county level and had significant spatial clustering of county-level higher education attainment across provinces. Moreover, model test results show that the spatial multilevel model was more suitable for our study than traditional regression models. Overall, transportation sustainability was significantly related to higher education attainment at the county level based on economy, society, environment, and politics, and dependent on socioeconomic backgrounds. This study is the first to understand the complexity of transportation sustainability by identifying variables that contribute to transport sustainability influencing higher education attainment and socioeconomic development based on impacting aggregate higher education attainment indicators. In particular, we take the politics dimension into consideration for transportation sustainability. Moreover, spatial lag and spatial clustering are included in the mechanisms. In addition, the intersection within transportation sustainability and between transportation sustainability and socioeconomic development affect higher education attainment by dividing China's provinces into five regions.

Our analysis offers complete evidence for the confounding role of the politics dimension in affecting the associations between transportation sustainability and higher education attainment, as well as the potential mediating role of the politics dimension in linking economic growth to higher education attainment. The results indicate that after considering the politics indicator, the coefficients of economy, society, and environment increase and are more significant. Moreover, the politics indicator is one of the potential mediators to indirectly influence higher education attainment. In addition, there is a strong correlation between the four dimensions of transportation sustainability and higher education attainment. In theory, this study has laid the groundwork for understanding the complex causal channels linking transportation sustainability to regional development. Furthermore, the results also suggest that transportation sustainability has robust influences on higher education attainment. Based on the associations between transportation sustainability and 
regional development, we have extended the research field of transportation sustainability and regional development by underlining the politics dimension and higher education attainment. In terms of policy implications, this study further promotes the roles of transportation sustainability and higher education in regional equalities. Attracting more skilled talent through the sustainable development of transportation is a powerful tool to reduce the regional gap.

Author Contributions: Conceptualization, K.C., J.X. and D.Z.; methodology, K.C. and D.Z.; software, D.Z.; formal analysis, K.C. and J.X.; investigation, D.Z.; resources, D.Z.; data curation, D.Z.; writing-original draft preparation, K.C. and D.Z.; writing-review and editing, J.X., K.C. and D.Z. All authors have read and agreed to the published version of the manuscript.

Funding: This research received no external funding.

Conflicts of Interest: The authors declare no conflict of interest.

\section{References}

1. Román, C.; Martin, J.C. Integration of HSR and air transport: Understanding passengers' preferences. Transp. Res. Part E Logist. Transp. Rev. 2014, 71, 129-141. [CrossRef]

2. Dargay, J.M.; Clark, S. The determinants of long distance travel in Great Britain. Transp. Res. Part A Policy Pract. 2012, $46,576-587$. [CrossRef]

3. Mabit, S.L.; Rich, J.; Burge, P.; Potoglou, D. Valuation of travel time for international long-distance travel—Results from the Fehmarn Belt stated choice experiment. J. Transp. Geogr. 2013, 33, 153-161. [CrossRef]

4. Ortega, E.; Lopez, E.; Monzón, A. Territorial cohesion impacts of high-speed rail under different zoning systems. J. Transp. Geogr. 2014, 34, 16-24. [CrossRef]

5. Arbués, P.; Baños, J.F.; Mayor, M.; Suárez, P. Determinants of ground transport modal choice in long-distance trips in Spain. Transp. Res. Part A Policy Pract. 2016, 84, 131-143. [CrossRef]

6. Cattaneo, M.; Malighetti, P.; Paleari, P.; Redondi, R. The role of the air transport service in interregional long-distance students' mobility in Italy. Transp. Res. Part A Policy Pract. 2016, 93, 66-82. [CrossRef]

7. Haapanen, M.; Tervo, H. Migration of the highly educated: Evidence from residence spells of university graduates. J. Reg. Sci. 2012, 52, 587-605. [CrossRef]

8. Ramani, T.; Potter, J.; Deflorio, J.; Zietsman, J.; Reeder, V.; Transportation Research Board; National Cooperative Highway Research Program. A Guidebook for Sustainability Performance Measurement for Transportation Agencies; National Academies Press: Washingotn, DC, USA, 2011.

9. Herb, C.; Pitfield, D.E. ELASTIC - A methodological framework for identifying and selecting sustainable transport indicators. Transp. Res. Part D Transp. Environ. 2010, 15, 179-188. [CrossRef]

10. Mahdinia, I.; Habibian, M.; Hatamzadeh, Y.; Gudmundsson, H. An indicator-based algorithm to measure transportation sustainability: A case study of the U.S. states. Ecol. Indic. 2018, 89, 738-754. [CrossRef]

11. Zhang, M.; Duan, F.; Mao, Z. Empirical Study on the Sustainability of China's Grain Quality Improvement: The Role of Transportation, Labour, and Agricultural Machinery. Int. J. Environ. Res. Public Health 2018, 15, 271. [CrossRef]

12. Choy, L.H.T.; Li, V.J. The role of higher education in China's inclusive urbanization. Cities 2017, 60, 504-510. [CrossRef]

13. Shen, Y.; Shen, M.; Chen, Q. Measurement of the new economy in China: Big data approach. China Econ. J. 2016, 9, 304-316. [CrossRef]

14. Radinger-Peer, V.; Pflitsch, G. The role of higher education institutions in regional transition paths towards sustainability. Rev. Reg. Res. 2017, 37, 161-187. [CrossRef]

15. Joumard, R.; Gudmundsson, H. (Eds.) Indicators of Environmental Sustainability in Transport; Les Collections de l'INRETS; European Commission: Brussels, Belgium, 2010.

16. Zhang, Y.; Guindon, B. Using satellite remote sensing to survey transport-related urban sustainability Part 1: Methodologies for indicator quantification. Int. J. Appl. Earth Obs. Geoinf. 2006, 8, 149-164. [CrossRef]

17. Li, F.; Liu, X.; Hu, D.; Wang, R.; Yang, W.; Li, D.; Zhao, D. Measurement indicators and an evaluation approach for assessing urban sustainable development: A case study for China's Jining City. Landsc. Urban Plan. 2009, 90, 134-142. [CrossRef]

18. Nourry, M. Measuring sustainable development: Some empirical evidence for France from eight alternative indicators. Ecol. Econ. 2008, 67, 441-456. [CrossRef]

19. Esteban, L.; Alfonso, T.S.; Cardenas, M.L. Systematic Review of Integrated Sustainable Transportation Models for Electric Passenger Vehicle Diffusion. Sustainability 2019, 11, 2513. [CrossRef]

20. Kraus, L.; Proff, H. Sustainable Urban Transportation Criteria and Measurement-A Systematic Literature Review. Sustainability 2021, 13, 7113. [CrossRef]

21. Kawabata, M. Job Access and Work among Autoless Adults in Welfare in Los Angeles. Ann. Assoc. Am. Geogr. 2002, 104, 1156-1182. 
22. Gurley, T.; Bruce, D. The effects of car access on employment outcomes for welfare recipients. J. Urban Econ. 2005, 58, 250-272. [CrossRef]

23. Cervero, R.; Sandoval, O.; Landis, J. Transportation as a Stimulus of Welfare-to-Work: Private Versus Public Mobility. J. Plan. Educ. Res. 2002, 22, 50-63. [CrossRef]

24. Li, T.; Burke, M.; Dodson, J. Transport impacts of government employment decentralization in an Australian city-Testing scenarios using transport simulation. Socio-Econ. Plan. Sci. 2017, 58, 63-71. [CrossRef]

25. Jonas, A.E.G.; Goetz, A.R.; Bhattacharjee, S. City-regionalism as a Politics of Collective Provision: Regional Transport Infrastructure in Denver, USA. Urban Stud. 2014, 51, 2444-2465. [CrossRef]

26. Bretos, I.; Errasti, A.; Marcuello, C. Multinational Expansion of Worker Cooperatives and Their Employment Practices: Markets, Institutions, and Politics in Mondragon. Ind. Labour Relat. Rev. 2019, 72, 580-605. [CrossRef]

27. McGuinness, S. Overeducation in the Labour Market. J. Econ. Surv. 2006, 20, 387-418. [CrossRef]

28. Leuven, E.; Oosterbeek, H. Overeducation and Mismatch in the Labour Market. In Handbook of the Economics of Education; Hanushek, E., Welch, F., Eds.; Elsevier: Amsterdam, The Netherlands, 2011. [CrossRef]

29. Di Paolo, A.; Matas, A.; Raymond, J.L. Job accessibility and job-education mismatch in the metropolitan area of Barcelona. Pap. Reg. Sci. 2017, 96, S91-S112. [CrossRef]

30. Büchel, F.; Van Ham, M. Overeducation, regional labour markets and spatial flexibility. J. Urban Econ. 2003, 53, 482-493. [CrossRef]

31. Hensen, M.M.; De Vries, M.R.; Cörvers, F. The role of geographic mobility in reducing education-job mismatches in the Netherlands. Pap. Reg. Sci. 2009, 88, 667-682. [CrossRef]

32. Jauhiainen, S. Overeducation in the Finnish regional labour markets. Pap. Reg. Sci. 2011, 90, 573-588. [CrossRef]

33. Ramos, R.; Sanromá, E. Overeducation and Local Labour Markets in Spain. Tijdschr. Econ. Soc. Geogr. 2013, 104, 278-291. [CrossRef]

34. Croce, G.; Ghignoni, E. Educational mismatch and spatial flexibility in Italian local labour markets. Educ. Econ. 2015, 23, 25-46. [CrossRef]

35. Devillanova, C. Over-education and spatial flexibility: New evidence from Italian survey data. Pap. Reg. Sci. 2013, 92, 445-464. [CrossRef]

36. Moreno-Monroy, A.I.; Lovelace, R.; Ramos, F.R. Public transport and school location impacts on educational inequalities: Insights from São Paulo. J. Transp. Geogr. 2018, 67, 110-118. [CrossRef]

37. Geurs, K.T.; Van Wee, B. Accessibility evaluation of land-use and transport strategies: Review and research directions. J. Transp. Geogr. 2004, 12, 127-140. [CrossRef]

38. Asahi, K. The Impact of Better School Accessibility on Student Outcomes; Political Science, SERC Discussion Paper; The London School of Economics: London, UK, 2014.

39. Falch, T.; Lujala, P.; Strøm, B. Geographical constraints and educational attainment. Reg. Sci. Urban Econ. 2013, 43, 164-176. [CrossRef]

40. Harland, K.; Stillwell, J. Using PLASC Data to Identify Patterns of Commuting to School, Residential Migration and Movement between Schools in Leeds; Working Paper No. 07/03; University of Leeds: Leeds, UK, 2007.

41. Wang, H.; Han, J.; Su, M.; Wan, S.; Zhang, Z. The relationship between freight transport and economic development: A case study of China. Res. Transp. Econ. 2021, 85, 100885. [CrossRef]

42. Zhu, J.; Li, B.; He, B.-J. Is linked migration overlooked in peri-urban Shanghai? Uncovering the domino effect of driving away interregional migrants. Habitat Int. 2019, 94, 102046. [CrossRef]

43. Lane, B.W. Revisiting 'An unpopular essay on transportation:' The outcomes of old myths and the implications of new technologies for the sustainability of transport. J. Transp. Geogr. 2019, 81, 102535. [CrossRef]

44. Klarl, T. Urban growth, transportation and the spatial dimension of the work market: A note: Urban growth, transportation and the work market. Pap. Reg. Sci. 2015, 94, 597-605. [CrossRef]

45. Fasihi, H.; Parizadi, T.; Agah, F. Analyzing Spatial Structure of Residence and Economic Activity in Relation with Transportation Infrastructures in Iran. Transp. Dev. Econ. 2021, 7, 1-7. [CrossRef]

46. Nezu, Y.; Fujii, S. Construction of simulation model masrac for impact analysis of the macro economy by transportation infrastructure investment. Stud. Sci. Technol. 2016, 5, 185-195. [CrossRef]

47. Thakuriah, P. Variations in employment transportation outcomes: Role of site-level factors. Pap. Reg. Sci. 2011, 90, 755-772. [CrossRef]

48. Kasu, B.B.; Chi, G. The Evolving and Complementary Impacts of Transportation Infrastructures on Population and Employment Change in the United States, 1970-2010. Popul. Res. Policy Rev. 2018, 37, 1003-1029. [CrossRef]

49. Pulipati, S.B.; Mattingly, S.P.; Casey, C. Evaluating state level transportation revenue alternatives. Case Stud. Transp. Policy 2017, 5, 467-482. [CrossRef]

50. Cai, Q.; Abdel-Aty, M.; Sun, Y.; Lee, J.; Yuan, J. Applying a deep learning approach for transportation safety planning by using high-resolution transportation and land use data. Transp. Res. Part A Policy Pract. 2019, 127, 71-85. [CrossRef]

51. Stanton, N.A.; Salmon, P.M. Planes, trains and automobiles: Contemporary ergonomics research in transportation safety. Appl. Ergon. 2011, 42, 529-532. [CrossRef] [PubMed]

52. Cervero, R.; Rood, T.; Appleyard, B. Tracking Accessibility: Employment and Housing Opportunities in the San Francisco Bay Area. Environ. Plan. A 1999, 31, 1259-1278. [CrossRef] 
53. Waqas, M.; Dong, Q.; Ahmad, N.; Zhu, Y.; Nadeem, M. Understanding Acceptability towards Sustainable Transportation Behavior: A Case Study of China. Sustainability 2018, 10, 3686. [CrossRef]

54. Ensslen, A.; Gnann, T.; Jochem, P.; Plötz, P.; Dütschke, E.; Fichtner, W. Can product service systems support electric vehicle adoption? Transp. Res. Part A Policy Pract. 2020, 137, 343-359. [CrossRef]

55. Glaeser, E.L.; Kahn, M.E. The greenness of cities: Carbon dioxide emissions and urban development. J. Urban Econ. 2010, 67, 404-418. [CrossRef]

56. Bergmann, A.; Colombo, S.; Hanley, N. Rural versus urban preferences for renewable energy developments. Ecol. Econ. 2008, 65, 616-625. [CrossRef]

57. Lehr, U.; Lutz, C.; Edler, D. Green jobs? Economic impacts of renewable energy in Germany. Energy Policy 2012, 47, 358-364. [CrossRef]

58. Rivers, N. Renewable energy and unemployment: A general equilibrium analysis. Resour. Energy Econ. 2013, 35, 467-485. [CrossRef]

59. Amirapu, A.; Hasan, R.; Jiang, Y.; Klein, A. Geographic Concentration in Indian Manufacturing and Service Industries: Evidence from 1998 to 2013. Asian Econ. Policy Rev. 2019, 14, 148-168. [CrossRef]

60. Anderson, C. Transnational Histories of Penal Transportation: Punishment, Labour and Governance in the British Imperial World, 1788-1939. Aust. Hist. Stud. 2016, 47, 381-397. [CrossRef]

61. Magalhães, A.; Veiga, A.; Ribeiro, F.; Amaral, A. Governance and Institutional Autonomy: Governing and Governance in Portuguese Higher Education. High. Educ. Policy 2013, 26, 243-262. [CrossRef]

62. Toro López, M.; Scheers, J.; Van den Broeck, P. The Socio-politics of the urbanization-Transportation nexus: Infra-structural projects in the department of Antioquia in Colombia through the lens of technological politics and institutional dynamics. Int. Plan. Stud. 2021, 26, 321-347. [CrossRef]

63. Gao, X.; Cao, M.; Yang, T.; Basiri, A. Transport development, intellectual property rights protection and innovation: The case of the Yangtze River Delta Region, China. Res. Transp. Bus. Manag. 2020, 37, 100563. [CrossRef]

64. Zhu, J.; Li, B.; Pawson, H. The end of 'toleration'? Policy ambiguity and converted-housing occupancy in China. Hous. Stud. 2020, 36, 479-499. [CrossRef]

65. Zhu, J.; Tang, W. Conflict and compromise in planning decision-making: How does a Chinese local government negotiate its construction land quota with higher-level governments? Environ. Urban. 2018, 30, 155-174. [CrossRef]

66. Collaborators, H. Global, regional, and national disability-adjusted life-years (DALYs) for 315diseases and injuries and healthy life expectancy (HALE), 1990-2015: A systematic analysis for the global burden of disease study 2015. Lancet 2016, 388, 1603-1658. [CrossRef]

67. Pierewan, A.C.; Tampubolon, G. Spatial dependence multilevel model of well-being across regions in Europe. Appl. Geogr. 2014, 47, 168-176. [CrossRef]

68. Gu, L.; Rosenberg, M.; Yang, L.; Yu, J.; Wei, B. A spatial multilevel analysis of the impacts of housing conditions on county-level life expectancy at birth in China. Appl. Geogr. 2020, 124, 102311. [CrossRef]

69. Luke, D. Multilevel Modeling; Sage Publications: Thousand Oaks, CA, USA, 2016.

70. Bivand, R.; Sha, Z.; Osland, L.; Thorsen, I.S. A comparison of estimation methods for multilevel models of spatially structured data. Spat. Stat. 2017, 21, 440-459. [CrossRef]

71. Taylor, B.; Kim, E.; Gahbauer, J. The Thin Red Line: A Case Study of Political Influence on Transportation Planning Practice. J. Plan. Educ. Res. 2009, 29, 173-193. [CrossRef]

72. Lauby, F. Transportation and immigrant political incorporation. J. Ethn. Migr. Stud. 2019, 206-222, 1-18. [CrossRef]

73. Cartier, C. What's territorial about China? From geopolitical narratives to the 'administrative area economy'. Euras. Geogr. Econ. 2013, 54, 57-77. [CrossRef]

74. Ma, L.J. Urban administrative restructuring, changing scale relations and local economic development in China. Political Geogr 2005, 24, 477-497. [CrossRef]

75. Lin, X.; MacLachlan, I.; Ren, T.; Sun, F. Quantifying economic effects of transportation investment considering spati-otemporal heterogeneity in China: A spatial panel data model perspective. Ann. Reg. Sci. 2019, 63, 437-459. [CrossRef]

76. Jiang, X.; Zhang, L.; Xiong, C.; Wang, R. Transportation and Regional Economic Development: Analysis of Spatial Spillovers in China Provincial Regions. Netw. Spat. Econ. 2016, 16, 769-790. [CrossRef]

77. Bonatti, L.; Campiglio, E. How can transportation policies affect growth? A theoretical analysis of the long-term effects of alternative mobility systems. Econ. Model. 2013, 31, 528-540. [CrossRef]

78. Nasreen, S.; Saidi, S.; Ozturk, I.; Johansson, N.; Robertson, L.; Weber, R. Assessing links between energy consumption, freight transport, and economic growth: Evidence from dynamic simultaneous equation models. Environ. Sci. Pollut. Res. Int. 2018, 25, 16825-16841. [CrossRef] [PubMed]

79. Fan, Y.; Guthrie, A.E.; Levinson, D.M. Impact of light rail implementation on labour market accessibility: A transportation equity perspective. J. Transp. Land Use 2012, 5, 28-39. [CrossRef]

80. López, F.A.; Paez, A. Spatial clustering of high-tech manufacturing and knowledge-intensive service firms in the Greater Toronto Area. Can. Geogr. 2017, 61, 240-252. [CrossRef]

81. De Vries, S.; Verheij, R.A.; Groenewegen, P.P.; Spreeuwenberg, P. Natural Environments—Healthy Environments? An Exploratory Analysis of the Relationship between Greenspace and Health. Environ. Plan. A 2003, 35, 1717-1731. [CrossRef] 
82. Ewing, R.; Tian, G.; Goates, J.P.; Zhang, M.; Greenwald, M.J.; Joyce, A.; Kircher, J.C.; Greene, W.H. Varying influences of the built environment on household travel in 15 diverse regions of the United States. Urban Stud. 2015, 52, 2330-2348. [CrossRef]

83. Wu, T.; Zhao, H.; Ou, X. Vehicle Ownership Analysis Based on GDP per Capita in China: 1963-2050. Sustainability 2014, 6, 4877-4899. [CrossRef]

84. Domonkos, S. Promoting a higher retirement age: A prospect-theoretical approach. Int. J. Soc. Welf. 2015, 24, 133-144. [CrossRef]

85. Zhai, K.; Gao, X. Higher education institutions and urban attraction: An empirical study based on 13 cities in Jiangsu Province. J. Xuzhou Inst. Technol. (Soc. Sci. Ed.) 2020, 35, 86-93. (In Chinese) 